\title{
NATURAL RESOURCES: PROVINCIAL PROPRIETARY RIGHTS, \\ THE SUPREME COURT OF CANADA, AND THE RESOURCE AMENDMENT TO THE CONSTITUTION WILLIAM D. MOULL*
}

\begin{abstract}
The 1982 "Resource Amendment" to the Constitution has important implications particularly for western oil producing provinces. The writer examines the "proprietary rights" theory relied upon by the Alberta Government by reviewing older case law and recent Supreme Court of Canada decisions. The writer suggests that many "proprietary rights' arguments which would likely be invalid may be saved by the resource amendment.
\end{abstract}

\section{INTRODUCTION}

Speaking in 1978, John B. Ballem warned the oil and gas producing provinces "to avoid any High Noon confrontation with Ottawa" while the Constitution remained unamended. ${ }^{1}$ His argument was that the producing provinces would lose any such confrontation in the end, because of the superior array of legislative powers available to the federal government. This would be the result, he concluded, notwithstanding widespread provincial Crown ownership of oil and gas resources in the producing provinces. ${ }^{2}$

The Constitution has now been amended, with the addition in 1982 of the "resource amendment" in section 92A. ${ }^{3}$ The introduction of the resource amendment has been welcomed enthusiastically in some quarters. Saskatchewan, for example, has already enacted an indirect production tax measure for its freehold oil and gas under the new powers conferred by subsection $92 \mathrm{~A}(4),{ }^{4}$ and plans a similar initiative in the taxation of its other minerals. ${ }^{5}$

Reaction to the introduction of section $92 \mathrm{~A}$ has been muted in the other Western provinces, notably Alberta and British Columbia. The reason seems to be the continuing belief of the governments of those provinces that their Crown proprietary rights already furnish them with the legislative and executive powers necessary to regulate all significant aspects of the development of their natural resources. Alberta in particular has long placed great emphasis upon its provincial proprietary rights as a principal source of jurisdiction over natural resources. In

* Of Davies, Ward \& Beck, Toronto, and Associate Professor, Osgoode Hall Law School, York University, Toronto.

1. Ballem, "Oil and Gas and the Canadian Constitution on Land and under the Sea" (1978) Law Society of Upper Canada Special Lectures 251 at 264.

2. Id. at p. 263.

3. Constitution Act, 1982 Part VI, sections 50 and 51; as enacted by the Canada Act, 1982 (U.K.), c.11.

4. The Freehold Oil and Gas Production Tax Act, S.S. 1982-83, c. F-22.1.

5. Saskatchewan Department of Energy and Mines, White Paper on Mineral Taxation in Saskatchewan (June 20, 1983). 
1974, for instance, former Alberta Energy and Natural Resources Minister Merv Leitch said: 6

In my view the key to the answer to nearly all questions of jurisdiction over natural resources lies in the ownership given to the provinces by The British North America Act. I want to stress that there is a very fundamental distinction between legislative control over those natural resources owned by the provinces and those owned privately .... Thus, from a practical point of view, so far as Alberta is concerned, and I think this is true of virtually all provinces and virtually all natural resources, we can ignore the question of which government has what legislative capacity over privately owned natural resources.

The essence of my point is that a provincial government under the constitution has vastly greater control over the natural resources it owns than it does over natural resources it doesn't own.

Underlying statements such as these is the assumption that a producing province has vastly greater powers over Crown-owned resources than it does over freehold resources, arising by virtue of provincial Crown ownership of all "lands, mines, minerals, and royalties" within the province under section 109 of the Constitution. ${ }^{7}$ The assumption made is that a producing province can do with its Crown-owned resources anything that a private owner of resources can do, and even more. ${ }^{8}$

In the energy wars of the last decade, Alberta relied extensively upon its theory of provincial proprietary rights. For example:

1. In the wake of the 1973 Arab oil crisis, Alberta enacted legislation to abolish the former maximum rate of Crown oil royalties of 16.6 per cent, ${ }^{9}$ and by regulation substituted a new Crown oil royalty schedule that included a supplemental royalty, at rates of up to 65 per cent, on the enhanced portion of the sale price of Alberta oil attributable to the increase in world prices. ${ }^{10}$ By legislation and regulation, Alberta also established the Alberta Petroleum Marketing Commission and gave that Commission the exclusive power to sell within Alberta both the Crown's royalty share and the Crown lessee's share of oil production. ${ }^{11}$

6. Leitch, "The Constitutional Position of Natural Resources", Address to Canadian Council of Resource and Environment Ministers, Victoria, British Columbia, November 21, 1974; reproduced in Meekison (ed.), Canadian Federalism: Myth or Reality (3d ed. 1977) 170 at 172-3.

7. Constitution Act, 1867 (U.K.), 30 \& 31 Vict., c.3. Combined, in the case of the Western provinces, with the 1930 Resource Transfer Agreements: see Constitution Act, 1930 (U.K.), $20 \& 21$ Geo. V, c. 26.

8. Bushnell, "Constitutional Law - Proprietary Rights and the Control of Natural Resources" (1980) 58 Can. Bar Rev. 157 at 158. See also Leitch, supra n. 6 at 173.

9. The Mines and Minerals Amendment Act, 1973, S.A. 1973, c. 94. For a fuller description of this legislation, see Thring, "Alberta, Oil, and the Constitution" (1979) 17 Alta. Law Rev. 69 at 86-7.

10. Alta. Reg. 93/74. The new royalty schedule is more fully described in Crommelin, "Jurisdiction over Onshore Oil and Gas in Canada" (1975-76) 10 U.B.C. Law Rev. 86 at 116-7.

11. The Petroleum Marketing Act, S.A. 1973, c.96; Alta. Reg. 304/74. See also Thring, supra n. 9 at 83-4, and Moull, "Natural Resources: The Other Crisis in Canadian Federalism" (1980) 18 Osgoode Hall Law Jo. 1 at 15. 
2. In response to the federal government's National Energy

Program of October 1980, Alberta ordered progressive cutbacks in Crown oil production. These cutbacks were ordered by regulation, pursuant to legislation enacted in anticipation of federal initiatives to capture a greater share of oil revenues otherwise accruing to Alberta. ${ }^{12}$

In both instances, Alberta enacted legislation in respect of its Crownowned oil resources under section 92(5) of the Constitution, which gives to the provinces legislative authority in relation to "the management and sale of the public lands belonging to the province and of the timber and wood thereon"'. In each case, the Alberta legislative initiatives were directed at oil resources that were the property of the Crown in right of Alberta under section 109 of the Constitution.

There are undoubtedly many strengths in the theory of provincial proprietary rights and many rights undoubtedly flow from provincial Crown ownership of resources. However, serious doubts can be raised regarding the extent to which the theory of provincial proprietary rights has been taken in initiatives like those of Alberta mentioned above. These doubts exist on two scores. First, can a producing province really do more in its capacity as proprietor of Crown resources than it can in its sovereign legislative capacity? Second, assuming that the Crown-proprietor can do more than the Crown-legislator, can it do so by the exercise of its legislative capacity rather than by the exercise of its executive capacity?

These doubts originate in the older case law that is of ten cited in support of the theory of provincial proprietary rights. A close examination of that older case law suggests that the Crown-proprietor can do more than the Crown-legislator, but that it can do so only through appropriate contractual mechanisms adopted in its executive capacity. However, the trend in more recent decisions of the Supreme Court of Canada suggests that the Court would not adopt that older case law without question. If so, then the older case law may no longer support a theory of provincial proprietary rights under which the powers of the Crown-proprietor are virtually unrestricted. As a result, Alberta's legislative initiatives in the last decade, as outlined above, could have been in serious jeopardy had they been challenged in the courts.

In the pages that follow, I will re-examine the older case law on provincial proprietary rights and outline the scope of the theory and its limitations, as well as the ways in which the theory has been extended in its implementation in recent years. I will then examine some of the more recent decisions of the Supreme Court of Canada, and attempt to assess how that Court would view the theory of provincial proprietary rights proposed in the older case law. In conclusion, I will suggest that the introduction of section 92A has far more relevance for a province like Alberta, which historically has relied extensively upon its proprietary rights, than that province itself may yet appreciate.

12. Maximum Petroleum Production Regulation, Alta. Reg. $325 / 80$, made pursuant to the The Mines and Minerals Amendment Act, 1980, S.A. 1980, c.32, s. 2. 


\section{THE OLDER CASES}

While a number of older decisions have discussed provincial proprietary rights, most of these have been concerned with the extent to which an exercise of federal legislative authority can interfere with provincial Crown property. ${ }^{13}$ Only three cases have dealt directly with an exercise of proprietary rights by a province. Two of these are the decisions often cited in support of a broad scope for the provincial proprietary rights theory; they are the 1900 decision of the Ontario Court of Appeal in Smylie v. The Queen, ${ }^{14}$ and the 1923 decision of the Privy Council in Brooks-Bidlake and Whittall, Limited v. Attorney General for British Columbia. ${ }^{15}$ The third case is another 1923 decision of the Privy Council, Attorney General of British Columbia v. Attorney General of Canada; ${ }^{16}$ it is rarely cited by proponents of provincial proprietary rights, because it undermines the apparent authority of the Brooks-Bidlake decision to which it is a counterpart.

In Smylie v. The Queen, the Ontario Court of Appeal upheld Ontario's "manufacturing condition". By virtue of this condition, all Crown timber cut under Ontario Crown timber licenses had to be manufactured into sawn lumber in Canada. The condition first appeared in Ontario regulations passed on December 17, 1897, which regulations were confirmed by an Ontario statute passed on January 17,1898 . The regulations and statute both required that the manufacturing condition be inserted in all Ontario Crown timber licenses issued after April 30, 1898. All prior licenses had a term of one year only, ending on April 30 in each year, so that the effect of the Ontario regulations and statute was to insert the manufacturing condition prospectively into all new licenses issued on or after May 1, 1898, whether or not those new licenses were in substitution for a prior license.

Smylie held an existing license for 1897-98, and sought to obtain a new license, effective May 1, 1898, without the inclusion of the manufacturing condition. The Ontario Court of Appeal held that he was not entitled to a license that did not contain the condition. The Court concluded that the Crown in right of Ontario had the power to determine upon what conditions it was prepared to dispose of its provincial public property, so that it was within the power of Ontario to dispose of its property on whatever terms and conditions it saw fit. As Osler, J.A. noted: ${ }^{17}$

In disposing of its own property, I conceive that the Legislature, to which is assigned, by section 92(5) of the British North America Act, exclusive jurisdiction over the management and sale of the public lands belonging to the Province and of the timber and wood thereon, must necessarily have power to prescribe that the licensee shall observe the conditions and regulations which may be attached to its acquisition.

13. See, for example, the Fisheries Reference [1898] A.C. 700 (P.C.); the Waters and WaterPowers Reference [1929] S.C.R. 200 (S.C.C.); Attorney General of Quebec v. Nipissing Central Railway [1926] A.C. 715 (P.C.) See also LaForest, Natural Resources and Public Property under the Canadian Constitution (1969), chapters 8 and 9, and cases discussed therein.

14. (1900) 27 O.A.R. 172.

15. [1923] A.C. 450 .

16. [1924]A.C. 203.

17. Supran. 14 at 180. 
This was the case, he concluded, even though it might have been argued that the manufacturing condition would have been invalid had it been imposed as a general legislative measure, on the theory that such a general prohibition against export in an unmanufactured state could have trenched upon exclusive federal jurisdiction over extra-provincial "trade and commerce" under section 91(2). However, in this instance the Ontario Legislature did not purport "to deal generally with timber which had become the property of private persons or corporations free from any condition on which it had been acquired from the Crown"; rather, "the Legislature was dealing with the public property of the Province and dictating the terms on which it might be acquired" ${ }^{18}$

Moss, J.A. took a similar approach on this point: ${ }^{19}$

I do not think the Act is open to the objection that it is ultra vires the Legislature of the Province. To begin with the subject matter is one in relation to which section 92 of the British North America Act declares that the Legislature may exclusively make laws. The legislation is in relation to the management and sale of the public lands belonging to the Province and the timber and wood thereon. It is of an administrative and directory character with regard to that species of provincial property. It is applicable to those dealing with the Crown Lands Department in respect of timber upon the public lands.

And I see no reason for thinking that the Legislature may not, in respect of this property, do what any subject proprietor might do, when proposing to dispose of his property, viz., attach to the contract a condition not impossible of performance, or unlawful per se, or prohibited by any existing law.

These are strong words indeed. They do not go so far as to suggest that the exercise of provincial proprietary rights would be exempt from the application of otherwise valid federal legislation actually enacted. It is clear, in fact, that valid federal legislation can affect provincially-owned Crown property to the same extent that it can affect privately-held property within a province. ${ }^{20}$ What these words do suggest, however, is that, in the absence of contradictory legislation at the federal level, the exercise of provincial proprietary rights can extend into areas otherwise exclusively reserved to Parliament under section 91 and thus forbidden to provincial legislatures under section 92 . If what is meant by this suggestion is that provincial legislation enacted under section 92(5) can intrude upon areas of federal legislative jurisdiction so long as no actual federal legislation puts a stop to that intrusion, then section 92(5) would have a much broader scope than any other head of provincial legislative power under section 92. ${ }^{21}$ For it is clear that no other head of provincial legislative authority under section 92 empowers a provincial legislature to enact laws on a subject matter otherwise within exclusive federal jurisdiction simply because Parliament has not enacted legislation on that subject matter. 22

Before accepting that suggestion at face value, however, it is important to remember the circumstances in which the Smylie decision arose. Clearly, the Court was not concerned with general provincial legislation under

18. Id. at 179-80.

19. Id. at 192.

20. See supra n. 13. See also Bushnell, supran. 8 at 158.

21. See Bushnell, supran. 8 at 160.

22. See, for instance, Central Canada Potash Co. Ltd. v. Government of Saskatchewan (1978) 88 D.L.R. (3d) 609 (S.C.C.) 
section 92(5). Rather, as Moss, J.A. pointed out, the legislation in question was "of an administrative and directory character" addressed to the provincial Crown Lands Department and those dealing with it. The regulations and statute in issue in Smylie did not themselves impose the condition. Instead, the regulations and statute required the provincial Crown to insert the manufacturing condition in all timber licenses issued after a certain date. In our system of responsible government based on the British parliamentary model, the Crown in right of a province cannot dispose of provincial public property without authorizing provincial legislation, and can only dispose of such provincial public property on the terms and conditions established by such authorizing provincial legislation. ${ }^{23}$ As MacLennan, J.A. noted in Smylie: ${ }^{24}$

No act of the government, or of any officer of the government will do, unless authorized by, and done in accordance with, the Acts of the Legislature.

Accordingly, what concerned the Court in Smylie was not a legislative step, but rather the terms and conditions of the contract under which the Crown in right of Ontario was prepared to dispose of its provincial public property. The terms and conditions of that contract were mandated by provincial legislation, and indeed the Crown in right of Ontario would have been powerless to dispose of its property without such legislation and was bound to dispose of its property only in accordance with such legislation. It is noteworthy that the regulations and statute in question in Smylie did not purport to affect any pre-existing licenses. Instead, the regulations and statute only prescribed prospectively the conditions upon which the provincial government would be permitted to dispose of Ontario Crown timber. The operative instrument was the timber license itself, not the regulations or statute. As MacLennan, J.A. also noted: ${ }^{25}$

What the first section of the Act says, is that all new sales, and all licenses issued in pursuance thereof, shall be subject to the condition mentioned in the first regulation, that is, the manufacturing condition, not that they shall be subject to that regulation itself, which, as well as the subsequent regulations, is not to come into force until the 29th of April.

Therefore, the real suggestion in Smylie is that the provincial Crown can only exercise its provincial proprietary rights in an extraordinary fashion when it does so by contract pursuant to authorizing legislation, and not that provincial legislation itself can operate in an extraordinary way. This interpretation of Smylie is borne out by the two 1923 decisions of the Privy Council, Brooks-Bidlake and Attorney General of British Columbia v. Attorney General of Canada, which reached opposite results on the same set of facts because of this very distinction.

These two decisions were concerned with a condition inserted in British Columbia Crown timber licenses, which condition prohibited the employment of Chinese or Japanese labour in connection with any such license. The British Columbia government had first required the insertion

23. Despite the belief of some in a residual royal prerogative permitting a provincial Crown to deal with its property without legislation (see Leitch, supra n. 6 at 173), it seems reasonably clear that no such residual prerogative exists and that authorizing legislation is thus a necessity (see Bushnell, supra n. 8 at 163-8).

24. Supra n. 14 at 182.

25. Id. at 187 . 
of the condition in all provincial Crown timber licenses by an Order in Council passed in May 1902. The timber license in question was first granted in 1912, for a one-year term that could be renewed annually if its terms and conditions had been complied with. The "Chinese or Japanese labour" condition was inserted in the original license, pursuant to the Order in Council of 1902, and remained in the license throughout its various renewals. It was clear that the company had employed both Chinese and Japanese labour in breach of the condition.

In 1913, pursuant to an Imperial treaty with Japan, the federal government enacted legislation according non-discriminatory treatment to subjects of the Empire of Japan. The basis for this legislation was in part section 91(25), by which Parliament has exclusive legislative jurisdiction over "naturalization and aliens", and in part section 132, which gave Parliament the power to implement treaty obligations of the British Empire. After an earlier provincial court decision in which the validity of the "Chinese or Japanese labour" condition was brought into question, in April 1921 British Columbia enacted a statute which retroactively confirmed the insertion of the condition in all outstanding timber licenses, and which further provided that any breach of the condition would be grounds for cancellation of the license. In August 1921, the British Columbia government threatened to cancel the license in question for breach of the condition, and when the license came up for renewal in February 1922 the British Columbia government refused to renew it, again on the grounds of breach of the condition.

The Brooks-Bidlake decision, ${ }^{26}$ like that in Smylie, concerned the insertion of the condition in the license itself. The company sought a declaration that the condition in its license was invalid, and that it was entitled to a renewal of its license notwithstanding its breaches of the condition. The Privy Council held that the company was not entitled to a renewal of its license. It considered that the Japanese Treaty was irrelevant to the question, because at the very least the condition was valid as regards Chinese labour. As the condition was valid, and as the company was in breach of it, the company was not entitled to a renewal. As Viscount Cave, L.C. said:27

\begin{abstract}
Each license is issued upon the understanding that no Chinese or Japanese shall be employed in connection therewith; and the appellants' right to renewal is contingent upon their complying with this stipulation. It appears from the indorsement of the writ in this action, as well as from para. 5 of the affidavit filed by the appellants in support of the motion, that they have employed and claim the right to employ both Chinese and Japanese labour. Now, whatever may be said as to the stipulation against employing Japanese labour, there is nothing (apart from the British North America Act) to show that a stipulation against the employment of Chinese labour is invalid. The stipulation is severable. Chinese and Japanese being separately named; and the condition against employing Chinese labour having been broken, the appellants have no right to renewal.
\end{abstract}

It appears that the company would not have been entitled to a renewal of its license even if the condition had been wholly invalid. The insertion of the condition in licenses was an integral part of the authority of the Crown in right of British Columbia to issue such licenses. As in Smylie, the provincial Crown could only dispose of its public property in ac-

26. Supran. 15.

27. Id. at 458. 
cordance with applicable legislation and regulations, and was thus required by statute and regulations to insert the condition in all licenses. A license not containing the "Chinese or Japanese labour" condition would thus have been a nullity, because the provincial Crown would have had no authority by or under legislation to issue such a license. This seems to have been the basis of the decision in the case in the Supreme Court of Canada, where the majority considered that the condition was wholly invalid but that the company still had no right to a renewal. ${ }^{28}$

On the other hand, the decision of the Privy Council in Attorney General of British Columbia v. Attorney General of Canada ${ }^{29}$ was concerned not with the insertion of the condition in the license itself, but with the validity of the 1921 British Columbia statute purporting to confirm its insertion in outstanding licenses and purporting to provide for cancellation of any such license upon breach of the condition. The 1921 statute itself was struck down because it conflicted with the federal legislation implementing the Imperial treaty with Japan. The Privy Council concluded that they faced a different question from the one decided in Brooks-Bidlake. As Viscount Haldane said: ${ }^{30}$

\begin{abstract}
In the appeal in the Brooks-Bidlake Case what their Lordships decided was that the stipulation in the licenses against the employment of Chinese was a severable stipulation which had been broken, with the result that the licensees could not claim a renewal. Such a stipulation was held to be in itself consistent with s. 91 , head 25 , and so far as Chinese labour was concerned no question could arise under the Japanese Treaty.

On the present occasion a wholly different question presents itself. The statute of 1921 not only confirms the stipulations provided for in the Orders in Council of 1902, but it enacts that where in any instrument of a similar nature to any of those referred to in these Orders a provision is inserted relating to or restricting the employment of Chinese or Japanese, the provision is to be valid and to have the force of law, and failure to observe it is to be ground for cancellation by the Provincial Government of the license or other instrument. Their Lordships observe that this provision may not altogether unreasonably be looked on as containing an approach to the laying down of something more than a mere condition for the renewal of the right to use Provincial property.
\end{abstract}

After concluding that the 1921 British Columbia statute conflicted with the federal statute of 1913 implementing the Japanese Treaty, Viscount Haldane also said: ${ }^{31}$

This conclusion does not in any way affect what they decided on the previous appeal as to the title to a renewal of the special licences relative to particular properties. It is concerned with the principle of the statute of 1921 , and not with that of merely individual instances in which particular kinds of property are being administered.

Some have suggested that this decision of the Privy Council clouds its earlier decision in Brooks-Bidlake. ${ }^{32}$ On the contrary, the subsequent decision clarifies the scope of Brooks-Bidlake and emphasizes that its true rationale, like that in Smylie, was based upon the contractual capacity there exercised by the Crown in right of British Columbia. What the provincial Crown could do by contract in Brooks-Bidlake it could not do

28. (1922) 63 S.C.R. 466; see also the summaries of the Supreme Court of Canada decision by Viscount Cave, L.C. [1923] A.C. 450 at 455-6, and by Viscount Haldane, [1924] A. C. 203 at 207-8.

29. Supran. 16.

30. Id. at 211 .

31. Id. at 212.

32. See, for instance, Crommelin, supra n. 10 at 104; Thring, supra n. 9 at 73. 
solely by legislation in exactly the same circumstances. Legislation enacted under section 92(5) thus stands in no better position as regards federal legislation and federal legislative authority than does any other provincial legislation enacted under section 92. The Crown-proprietor can do more than the Crown-legislator, but must do so by appropriatelyframed contractual conditions attached to its dispositions of Crownowned resources. When the operative instrument is the legislation itself, rather than the contract to which such legislation is directed, the provincial Crown stands in no higher position than it would under any other provincial legislation. Little wonder, then, that the later decision of the Privy Council is usually overlooked by advocates of provincial proprietary rights who, by and large, have exercised those rights through legislation directed at existing contractual provisions rather than by negotiated amendments to the contract itself.

\section{EXTENSION OF THE THEORY}

Other decisions have suggested ways of extending the powers that a provincial Crown may exercise when acting by contract in its executive capacity. A striking example is Attorney General of British Columbia v. The Deeks Sand \& Gravel Company Limited. ${ }^{33}$ There, the Supreme Court of Canada upheld a variable royalty clause contained in an agreement between the Crown in right of British Columbia and the holder of two quarrying leases. There had previously been some dispute between the provincial Crown and the lessee regarding the right of the former to exact a royalty at all, and the agreement in question was the result of negotiations that settled the earlier dispute. The Court upheld the terms of the agreement, on the ground that the agreement itself was valid notwithstanding any constitutional limitation to which the provincial Crown might have been subject in respect of the earlier dispute. This decision reinforces that of the Privy Council in Attorney General of Alberta v. Huggard Assets Ltd., ${ }^{34}$ which confirmed the enforceability of a variable royalty clause that obligated a Crown lessee to pay "such royalty, if any, from time to time prescribed by regulations". The provincial Crown could thus vary the rate of royalty by regulation at will, because that right was expressly reserved in the Crown lease itself (the Supreme Court of Canada having previously indicated that express language in a Crown lease would be required to reserve that right to the provincial Crown). ${ }^{35}$

Building on cases such as these, provincial governments have developed imaginative drafting techniques as a way to extend the theories first enunciated in Smylie and Brooks-Bidlake. One of these is the variable royalty clause common in provincial Crown petroleum and natural gas leases, under which the lessee obligates himself to pay whatever rate of royalty might be prescribed by regulation from time to time. A similar provision is the so-called "compliance with laws" clause under which, as a condition of his Crown lease, the lessee obligates

33. [1956] S.C.R. 336.

34. [1953]A.C. 420.

35. Attorney General for Alberta v. Majestic Mines Limited [1942] S.C.R. 402. 
himself to comply with all provincial statutes and regulations in force from time to time. ${ }^{36}$ At its extreme, such a clause would incorporate into the Crown lease by reference all provincial statutes and regulations as they are enacted or amended, and would thus give a province the apparent ability to amend the contractual terms of the Crown lease unilaterally by legislation. In theory, the contract would still be the operative instrument, not the incorporated legislation. Some have suggested, however, that there may be certain "core terms" of the contract which cannot be unilaterally amended by the provincial government under the "compliance with laws" clause. ${ }^{37}$ There is no doubt that even these "core terms" can be overridden by a province acting in its soverign legislative capacity. The issue would be whether provincial legislation, incorporated by reference into a provincial Crown lease by virtue of the "compliance with laws" clause, can effect a unilateral amendment of those "core terms" as a matter of contract rather than legislation.

It was clearly this extension of the Smylie and Brooks-Bidlake theories upon which Alberta relied in its 1973 and 1980 legislative actions outlined above. ${ }^{38}$ In 1973, after abolishing by statute the maximum rate of Crown oil royalties, Alberta amended its Crown oil royalty schedule under the variable royalty provision in Alberta Crown petroleum and natural gas leases. ${ }^{39}$ Similarly, the general "compliance with laws" clause in Alberta Crown petroleum and natural gas leases would be the foundation for applying to Crown lessees, as a matter of contract, the 1973 legislated interposition of the Alberta Petroleum Marketing Commission, particularly with respect to the Crown lessee's own share of production. ${ }^{40}$ That clause would also underlie the authority for the implementation of the 1980-81 progressive reductions in Crown oil production rates.

These steps by Alberta clearly stretch the proprietary rights theory to its limits. Smylie and Brooks-Bidlake are only clear authority for the proposition that binding contractual provisions can permit a provincial Crown to do more with respect to Crown-owned resources by contract than it could otherwise do by legislation. None of these moves by Alberta fits squarely within that description. The validity of Alberta's legislative steps in the last decade, as a matter of contract, thus depends upon the view that the courts take of the referential incorporation technique employed so extensively by Alberta. Failure of that referential incorpora-

36. For a discussion of clauses of this kind, see Thompson, "Sovereignty and Natural Resources - A Study of Canadian Petroleum Legislation"' (1969) 4 U.B.C. Law Rev. 161 at 183-5.

37. See Harrison, "The Legal Character of Petroleum Licences" (1980) 58 Can. Bar Rev. 483 at 505-8. See also Thring, supra $\mathrm{n} .9$ at 79, and Thompson, supra $\mathrm{n}$. 36 at 186-8.

38. Supran. 9 to 12 .

39. The Alberta variable royalty clause, along the lines of that upheld in the Huggard Assets decision, supra $n .34$, requires the lessee to pay "a royalty . . . at the rate or rates as are now or may from time to time be prescribed by the Lieutenant Governor in Council".

40. The Alberta "compliance with laws" clause is drawn very broadly. It requires compliance with "the provisions of The Mines and Minerals Act, as amended, and any Act passed in substitution therefor, and with any regulations now made or that at any time may be made under the authority of the said Acts, and all the provisions and regulations that prescribe, relate to or affect the rights and obligations of lessees of petroleum and natural gas rights that are the property of the Crown in right of Alberta". 
tion technique in the eyes of a court would not necessarily be fatal, because Alberta could still argue in favour of its sovereign legislative authority to enact those measures. However, for reasons that will be discussed below, it is unlikely that Alberta could have sustained measures of this kind under its legislative powers in section 92. Accordingly, the validity of these measures would have had to stand or fall upon the degree to which a court was prepared to find them to be an appropriate exercise, by contract, of Alberta's executive capacity as the Crownproprietor.

Alberta was not challenged in the courts on any of these steps, principally because its Crown lessees were unwilling to incur the political and economic consequences that would flow from such a challenge, whether successful or unsuccessful. ${ }^{41} \mathrm{Had}$ any of these steps been challenged, there is a good chance that each would have been held invalid. For if the referential incorporation technique was a permissible extension of the Smylie and Brooks-Bidlake theory in earlier times, more recent decisions of the Supreme Court of Canada indicate that the Court might not be prepared to adopt that aspect of the theory of proprietary rights. There are even some suggestions that, had the matter been brought before it in the last decade, the Supreme Court of Canada might have overruled Smylie and Brooks-Bidlake and thus have confined the scope of provincial proprietary rights to the same limits as those imposed upon any provincial legislative initiative under section 92.

\section{CIGOL AND ONWARDS}

It is important to note that Smylie and Brooks-Bidlake were decided in an era in which the scope of the federal "trade and commerce" power under section 91(2) was considerably reduced from what we now know it to be. At one point in the 1920's, just before and after the Privy Council decision in Brooks-Bidlake, the Privy Council had even suggested that the trade and commerce power had no independent life, and could be invoked to justify federal legislation only in aid of some other jurisdiction conferred on Parliament under section 91.42 While there are still some doubts about its exact bounds, there is no question that the trade and commerce power underwent a significant renaissance since the time of Smylie and Brooks-Bidlake. It should not be surprising, then, that the modern view of the trade and commerce power in the Supreme Court of Canada leaves less room for the operation of provincial legislation than previously. Nor should it be too surprising that this re-emergence of the trade and commerce power was responsible, in large measure, for the ill fate awaiting the Saskatchewan Government in Canadian Industrial Gas \& Oil Ltd. v. Government of Saskatchewan. ${ }^{43}$

In CIGOL, the Supreme Court of Canada had to consider three elements of Saskatchewan's response to the 1973 Arab oil crisis. One of these was its expropriation of all oil and gas rights in producing tracts

41. See Thring, supra n. 9 at 89. See also Harrison, supran. 37 at 505-8.

42. Crommelin, supra n. 10 at 98 ; Ballem, "Constitutional Validity of Provincial Oil and Gas Legislation" (1963) 41 Can. Bar Rev. 199 at 211.

43. (1977) 80 D.L.R. (3d) 449. 
held in freehold by those owning more than 1,280 acres. This aspect of Saskatchewan's legislation was upheld, but the two other features were struck down. These features were a "mineral income tax" imposed upon oil production from freehold lands, the tax being measured as 100 per cent of the difference between the former and newly-enhanced prices of Saskatchewan oil. The other was a "royalty surcharge" that was imposed in similar fashion upon oil produced both from the formerly freehold lands that were expropriated under the legislation and from those lands that had been Crown-owned all along.

Several aspects of the CIGOL decision are open to criticism, particularly the conclusion of the majority in the Supreme Court of Canada that both the "mineral income tax" and the "royalty surcharge" were invalid as indirect provincial taxation. ${ }^{44}$ For present purposes, however, what is important is the conclusion in the case that Saskatchewan's "royalty surcharge" was really just a tax. This was a unanimous conclusion, it should be noted, of both the majority and the minority in the Supreme Court.

This conclusion is not particularly surprising in respect of the Crownacquired lands that were expropriated under the legislation. In respect of those lands, the Crown in right of Saskatchewan stepped into the shoes of the freehold lessor and, accordingly, could acquire no greater rights by virtue of the expropriation than the freehold lessor had immediately before then. As the Court found, leases of this kind fixed the royalty payable by the lessee, giving the lessor no right to amend the rate of royalty unilaterally. ${ }^{45}$ Accordingly, Saskatchewan could only impose an additional levy upon its Crown-acquired lessees by the exercise of its taxation powers under section 92(2).

What is somewhat surprising, at least to a proponent of provincial proprietary rights, is that the majority of the Court reached exactly the same conclusion with respect to the imposition of the "royalty surcharge" upon those who were truly Crown lessees and had been all along. Saskatchewan Crown leases contained a variable royalty clause much like that used elsewhere, including Alberta. ${ }^{46}$ Under the traditional theory of provincial proprietary rights, including the principle of referential incorporation represented in cases such as Huggard Assets, ${ }^{47}$ Saskatchewan had followed the proper process to vary its Crown oil royalty rates, by enacting a new royalty schedule by regulation pursuant to the variable royalty clause in its provincial Crown leases. Yet the majority of the Court concluded in short order that the "royalty surcharge" was nothing more than a tax even when applied to pre-existing Crown lessees. ${ }^{48} \mathrm{Little}$

44. Moull, supra n. 11 at 23-5; Paus-Jenssen, "Resource Taxation and the Supreme Court of Canada: The Cigol Case"' (1979) 5 Can. Pub. Policy 45 at 53.

45. Supra n. 43, per Martland, J. at 458-9, per Dickson, J. at 483-4.

46. The clause in question required a lessee to pay "any royalties at such rates and in such manner and at such times as are from time to time prescribed by the Order of the Lieutenant Governor in Council": supra n. 43 at 459.

47. Supra n. 34.

48. Supra n. 43, per Martland, J. at 459 . The minority decision suggested that there might be some distinction to be made between the Crown-acquired lessees and the pre-existing Crown lessees, but did not pursue the point in view of its conclusion that the "royalty surcharge" was a tax in any event: supra n. 43 per Dickson, J. at 484. 
reasoning was offered for this conclusion, and Smylie, Brooks-Bidlake and the cases on variable royalties were not even mentioned. Yet the conclusion was unequivocal.

As a result of this conclusion, the majority decision went on to hold that the "royalty surcharge" was an indirect tax, and thus beyond provincial legislative competence under section 92(2) of the Constitution which limits the provinces to "direct taxation". There is a marked resemblance between Saskatchewan's "royalty surcharge" measures and Alberta's 1973 Crown oil royalty changes, and commentators speaking before the release of the Supreme Court of Canada decision in CIGOL had concluded that both were valid on the same footing, as provincial legislation enacted under section 92(5) in relation to provincial Crown proprietary rights..$^{49}$ Others, speaking after the decision was released, attempted to distinguish Alberta's scheme from Saskatchewan's but without success, and have been forced to conclude that Alberta's royalty changes stood in an extremely precarious position. ${ }^{50}$ This assessment is undoubtedly correct, but not only because of the structural resemblances between the Saskatchewan and Alberta schemes. For the short work that the majority decision in CIGOL made of any suggestion that the Saskatchewan "royalty surcharge" was a permissible variation in Crown royalty rates also indicates a marked retreat from the theory of provincial proprietary rights under which provinces like Alberta have been operating for many years. The significance of $C I G O L$ on this point goes far beyond the specific provincial scheme it considered, and casts serious doubts upon all provincial schemes in the resource field that had been founded upon the referential incorporation technique. If the Supreme Court of Canada is not prepared to abide by a variable royalty clause, which is comparatively explicit and specific in its import, then it is not very likely that the Court would abide by the much more generally-phrased "compliance with laws" clauses upon which other provincial initiatives have been founded.

It would thus seem that Alberta's 1973 legislation regarding the Alberta Petroleum Marketing Commission, and its 1980 legislation authorizing mandatory reductions in Crown oil production rates, would also have failed had they been challenged up to the Supreme Court of Canada. In both instances, the major thrust of the provincial initiative was to interfere in some way with the extra-provincial marketing of Alberta oil. As a purely legislative matter, these initiatives probably would founder on the resurgent federal authority over extra-provincial "trade and commerce" in section 91(2). They might have been valid had they been adopted by appropriate contractually-binding amendments to Crown leases, for that would have brought the initiatives back into the heart of Smylie and Brooks-Bidlake. However, as contractual terms purportedly inserted by legislation referentially incorporated into Crown leases, they are no more contractual terms than was Saskatchewan's "royalty surcharge"'.

49. See, for instance, Crommelin, supra n. 10 at 116-8.

50. Thring, supran. 9 at 87-9. 
CIGOL is not the only adverse indication to emerge from the Supreme Court of Canada in recent years. Some dicta in the recent Alberta Natural Gas Tax Reference ${ }^{51}$ also suggest that the Supreme Court of Canada would not even pay much respect to the more limited theory of provincial proprietary rights that clearly emerges in Smylie and Brooks-Bidlake. In its argument in that case, Alberta pushed very strongly its view that its provincial proprietary rights are of a higher order than those of the original provinces under section 109. This argument was based upon an interpretation of the 1930 Natural Resources Transfer Agreement between Canada and Alberta, ${ }^{52}$ which it was argued vested Crownowned resources in Alberta notwithstanding anything else in the Constitution. This argument, if successful, would have meant that Alberta Crown-owned resources would be immune from all federal legislative authority under section 91 .

The majority decision politely dismissed this argument, because it was prepared to hold in any event that Alberta-owned natural gas was not subject to federal taxation by virtue of section 125 of the Constitution..$^{53}$ However, the minority of the Court (which included Laskin, C.J.C.) was far less polite in its dismissal of the argument. The minority noted that the context of the 1930 Natural Resources Transfer Agreement appeared to put Alberta in the same position as the original provinces, not a superior position. It also noted that the logical consequence of the argument would be that Alberta would not be subject to any limiting terms of the Constitution in respect of its natural resources. That said, the minority concluded, "there is no need to say anything more on what is a farfetched submission"'.54

Perhaps one should not make too much of such brief comments, but the tone is noteworthy. The Supreme Court of Canada has not been presented squarely with the issues arising from Smylie and Brooks-Bidlake, so it is impossible to say with certainty how they would fare in front of the present Court. There is a good likelihood, however, that those who suggest that Smylie and Brooks-Bidlake were wrongly decided would be vindicated if the present Court was ever faced with that issue. ${ }^{55}$ Even if they are not overruled expressly, the Court would be entirely free to ignore them, just as it did in CIGOL and just as it has done in other recent instances. ${ }^{56}$

51. Reference Re Proposed Federal Tax on Exported Natural Gas (1982) 136 D.L.R. (3d) 385.

52. Supran. 7.

53. Supran. 51 at 428.

54. Id. at 407.

55. See, for instance, Bushnell, supran. 8 at 160-2.

56. See, Harrison, "Natural Resources and the Constitution: Some Recent Developments and Their Implications for the Future Regulation of the Resource Industries" (1980) 18 Alta. Law Rev. 1 at 11 , fn. 45. 


\section{THE RESOURCE AMENDMENT}

Section 92A was introduced into the Constitution on April 17, 1982, as part of the constitutional patriation package. ${ }^{57}$ I suggested at the outset that the introduction of section $92 \mathrm{~A}$ was welcomed enthusiastically by provinces like Saskatchewan, which have relatively large concentrations of privately-held resources that are thus beyond the reach of any exercise of provincial proprietary rights. I also suggested, however, that even those provinces, like Alberta, which have traditionally relied heavily upon their proprietary rights in resource-related matters can benefit from the introduction of section $92 \mathrm{~A}$, indeed more than they may yet appreciate. This suggestion can be illustrated by reference to the kinds of legislative initiatives that Alberta has pursued in the past decade.

To begin with, Alberta's 1973 Crown oil royalty changes were likely invalid as an exercise of provincial proprietary rights because they did not adhere to the contractual process authorized by decisions like Smylie and Brooks-Bidlake. As taxation measures, they too would have suffered the fate of Saskatchewan's "royalty surcharge", as indirect taxation beyond the permissible limits of section 92(2) of the Constitution. However, under subsection 92A(4), Alberta's royalty changes would have been saved even if they were indirect taxation. For the first time, subsection 92A(4) authorizes the producing provinces to impose "any mode or system of taxation" upon natural resources in the province and upon the "primary production therefrom". This language clearly authorizes the imposition of indirect as well as direct taxation by a producing province, and thus would validate any future Crown oil royalty changes by Alberta that could not be supported under a theory of provincial proprietary rights.

In 1973, Alberta also enacted legislation to interpose the Alberta Petroleum Marketing Commission between its Crown oil producers and their purchasers outside Alberta. While such a scheme might be valid if it were limited to marketing only Alberta's Crown oil royalty share, the scheme applies as well to the Crown lessee's share of production. In this respect, without adequate foundation in provincial proprietary rights, the legislation would appear to be invalid because it interferes with extraprovincial trade in Alberta oil after production. Before the introduction of section 92A, only Parliament could legislate in relation to the export of resource production from a province.

Now, under subsection $92 \mathrm{~A}(2)$, the producing provinces have a concurrent legislative jurisdiction with Parliament in relation to the export of resource production from the province when that production is destined for "another part of Canada". In recent years, almost all of Alberta's oil has gone to markets in Eastern Canada, and so to that extent at least Alberta's petroleum marketing system would be saved by subsection $92 \mathrm{~A}(2)$ even if it intruded upon an area formerly reserved exclusively to Parliament. Any such provincial "export" legislation under subsection

57. Supra n. 3. For a fuller discussion of the effect of the resource amendment, see Moull, "Section 92A of the Constitution Act, 1867", to be published in (1983) 61 Can. Bar Rev., and Moull, "The Legal Effect of the Resource Amendment - What's New in Section 92A?", to be published in late 1983 by The Institute for Research on Public Policy. 
92A(2) would still be subject to overriding federal legislation by virtue of subsection $92 \mathrm{~A}(3)$, but in the absence of any contradictory federal legislation the concurrent field is clear for provincial legislation.

In 1980, Alberta ordered reductions in the rates of production of Crown oil. Again, there must be considerable doubt as to the validity of these orders as a proper exercise of provincial proprietary rights. As legislated requirements, they were likely invalid before the introduction of section $92 \mathrm{~A}$ because their purpose and effect were clearly to reduce the supplies of Alberta oil flowing to Eastern Canada.

Those orders, and the statutory provision under which they were made, would also likely be valid legislation under section $92 \mathrm{~A}$. To the extent that such orders were aimed at "export" of oil from Alberta, then in the absence of contrary federal legislation they probably could have been supported under subsection 92A(2). More important, however, is clause 92A(1)(b), which gives to the producing provinces exclusive legislative jurisdiction in relation to "development, conservation and management" of non-renewable natural resources within the province, and specifically includes therein laws in relation to the "rate of primary production" from those resources.

In all three instances, and in comparable situations in the future, section 92A represents an additional shield for provincial resource-related legislative initiatives. This is not to say that there is nothing at all in the theory of provincial proprietary rights, for indeed there is. But there is likely far less in the present-day theory of provincial proprietary rights than its advocates believe. Accordingly, section 92A gives the provinces, and particularly Alberta, an independent legislative basis to supplement the powers enjoyed by them in their capacity as proprietors of Crownowned resources. 